\title{
6
}

\section{Agriculture in the Australia-EU economic and trade relationship}

\author{
Karen Hussey and Carl Tidemann
}

\section{Introduction}

Following the collapse of the Doha Development Agenda, two dominant trends have emerged in the international system of trade. The first is the proliferation of bilateral and regional free trade agreements ${ }^{1}$ (FTAs) as an 'operational second best' approach to multilateral regulation (Bonciu \& Moldoveanu 2014). Such agreements are second best because they impose significant transaction costs on the international system of trade (i.e. exporters can be forced to handle sometimes dozens of different regulatory regimes concurrently), and they only occasionally produce significant trade gains in those areas that are particularly sensitive such as in agriculture and labour-intensive manufactured products (WTO 2013; Viju \& Kerr 2011). Despite these drawbacks, hundreds of FTAs have been negotiated over the last two decades and some optimism is warranted; at the very least, the size of the markets and the number of countries covered by some FTAs suggest that it may eventually be easier to return to the World Trade Organization (WTO) for a truly global trade

\footnotetext{
1 Such agreements are also called preferential trade agreements (PTAs), for example by the WTO, but in this chapter we will use the more commonly used term free trade agreement.
} 
agreement because some regulatory reform under FTAs are intrinsically non-discriminatory, leading to a de facto most-favoured-nation dividend (WTO 2013: 24).

The second trend in recent years has been the rise of non-tariff barriers (NTBs) as impediments to trade between nations. Other than to tell us what they are not, the term NTB itself does not reveal any of the details of what they include. Nevertheless, they are, generally, all measures other than tariffs that restrict or otherwise distort trade flows (OECD 2005). More broadly, such measures could be customs rules and procedures, competition-related restrictions on market access, public procurement practices, or internal taxes or charges. Specifically, they may relate to requirements around labelling, certification, packaging, and health and safety standards. The challenge for the international system of trade governance is to balance the imperative of free trade with legitimate domestic concerns and expectations relating to social and environmental public good outcomes, a challenge acknowledged by the WTO:

While a convergence of public policy design would facilitate matters from a purely trade perspective, we recognise that respect for differing social preferences is paramount. We must work towards a shared understanding of what constitutes a level playing field (WTO 2013: 29).

Establishing 'convergence of public policy design' is where regional and bilateral agreements can be very useful. Despite the fact that high tariffs are still evident in key product areas, including agricultural products, more than four-fifths of international trade flows take place on a non-discriminatory basis, which means that regulations are far more important as potential trade barriers and sources of discrimination (WTO 2013: 25-6). Thus, while such FTAs can never achieve the same gains as multilateral agreements, they do nevertheless provide significant opportunities for trading partners to forge ahead in reducing traditional trade barriers as well as behind-the-border trade barriers (Hussey \& Kenyon 2011). In very recent years there has been a revival in anti-free trade sentiment, most vehemently in the United States where vocal members of both the Republican and Democrat parties have objected to US ratification of the 12-nation Trans-Pacific Partnership Agreement and negotiations for the Trans-Atlantic Trade and Investment Partnership (Irwin 2015). Similar sentiments are also evident in parts of Europe, and the BREXIT 'Leave' campaign based at least some of their campaign on the perception that free trade between the EU and UK had failed to deliver promised gains. 
However, those sentiments notwithstanding, the opportunities that an EU-Australia FTA offer are the motivation for the recent announcement on 15 November 2015 by the Australian Prime Minister, together with the President of the European Council and the President of the European Commission, to start the process towards a 'comprehensive and high-quality' FTA (DFAT 2015). As a bloc, the European Union (EU) is Australia's second-largest trading partner and largest source of foreign investment: in 2014, the EU's FDI in Australia was valued at A $\$ 169.6$ billion and Australian FDI in the EU was valued at A $\$ 83.5$ billion (DFAT 2015).

For Australia, a bilateral agreement with the EU could provide better access to over 500 million consumers and help it to attract additional investment, technology, and skilled workers from Europe. However, as was the case in the Canada-EU negotiations towards the Comprehensive Economic and Trade Agreement (CETA, see Chapter 4 in this volume), some of the predictable, sensitive issues that will challenge the Australia-EU negotiations relate to agriculture. They include tariffs and quotas, but negotiators will also have the opportunity to deal with a range of NTBs, including packaging, labelling, certification (technical barriers to trade-TBTs), and health and safety standards (sanitary and phytosanitary—SPS standards) (Viju \& Kerr 2011).

The objective of this chapter is to assess the major challenges that Australian and European negotiators will face in tackling the agricultural trade barriers that exist between the two trading partners. The asymmetry of the relationship prompts us to take a largely Australian perspective on the benefits to be gained in the agricultural sector from an Australia-EU FTA. This chapter is informed by statistical analysis of the current trading relationship; 15 interviews with key industry peak bodies and government departments; analysis of previous FTAs involving Australia and the EU; submissions to government enquiries; and the peer-reviewed academic literature. It begins by outlining the agri-trade relationship between Australia and the EU, then assesses the extent of traditional barriers that exist in agricultural trade between the two markets. It analyses the range of NTBs that currently impinge on the trading relationship and which could therefore usefully form the focus of trade negotiations, and proposes a number of ways forward to achieve greater convergence and coherence between the EU's and Australia's trade rules and the policies, norms and standards in other areas of public policy that create NTBs. 


\section{Agricultural trade between Australia and the EU}

The EU and Australia have a long economic and diplomatic history governed most recently by the 1997 Australia-EU Partnership Framework, the 2008 Wine Agreement and a mutual recognition agreement (MRA) relating to industrial products. However, the relationship has historically been characterised by a high level of antagonism, caused by, on the one hand, the EU's trade-distorting policies under the common agricultural policy (CAP) and their immovable stance on geographic indicators (see Chapter 7 in this volume), and on the other hand, Australia's strict quarantine and biosecurity regimes (Kenyon \& Lee 2006; Kenyon \& Kunkel 2005). However, iterative reform of the CAP throughout the 1990s, and especially since 2003, introduced a number of important innovations including a fundamental change to the decoupling of income support payments to farmers freeing them up to produce for the market and not for subsidies (i.e. a less trade-distorting approach) (Costa et al. 2009; and for further detail see Chapter 5 in this volume).

Two further reforms included the introduction of cross-compliance to ensure that farmers only receive financial support if they meet minimum good agricultural, animal welfare and environmental practices; and a shift from market support to rural development objectives (i.e. building capacity and diversification in regional areas, retaining young farmers on the land etc.). In the following years, those sectors still considered to be in surplus (e.g. sugar, fruit and vegetables and wine sectors) were also reformed, and a new rural development policy for the financial period 2007-13 was prepared. The 'heat' in the relationship has also lessened owing to a shift in focus by Australian exporters to growing markets in Asia and the Middle East, and a relative decline in Australia's market share to the EU due to increased competition from Brazil, China and South Africa-the same dynamics that saw the United States of America (USA) share of the EU market decline.

Despite the rise of Asia and the Middle East as key trading partners, at the time of writing the EU is second only to China as Australia's largest trading partner (DFAT 2017b). The EU is the third-largest export market for Australian goods behind China and Japan, and is the largest source of Australia's imports ahead of both China and the USA. But the relationship is an entirely asymmetrical one: Australia represents just 1.7 per cent of the 
EU's export market and a mere 0.5 per cent of EU imports (DFAT 2017a). Imports from the EU are made up almost completely of manufactured goods as well as medicines and pharmaceutical products (Figure 1).

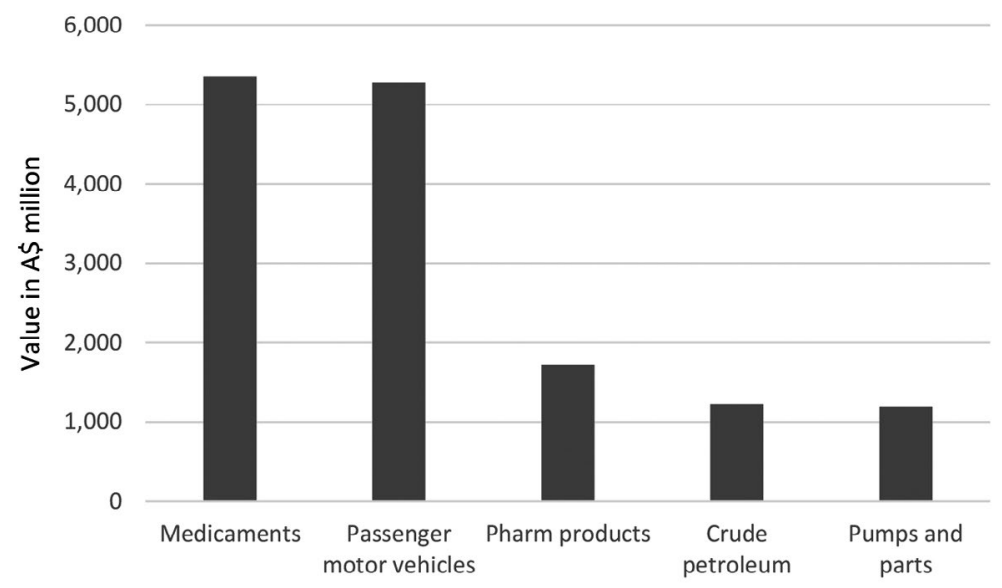

Figure 1. Top five Australian imports from the EU

Source: DFAT 2017a.

Australia's agricultural exports to the EU represent 18 per cent of all exports to the EU, with a total value of $\mathrm{A} \$ 2.77$ billion (coal is Australia's secondlargest export commodity to the EU at 15 per cent) (ABARES 2014; DFAT 2017b). Figure 2 shows the key agricultural export commodities.

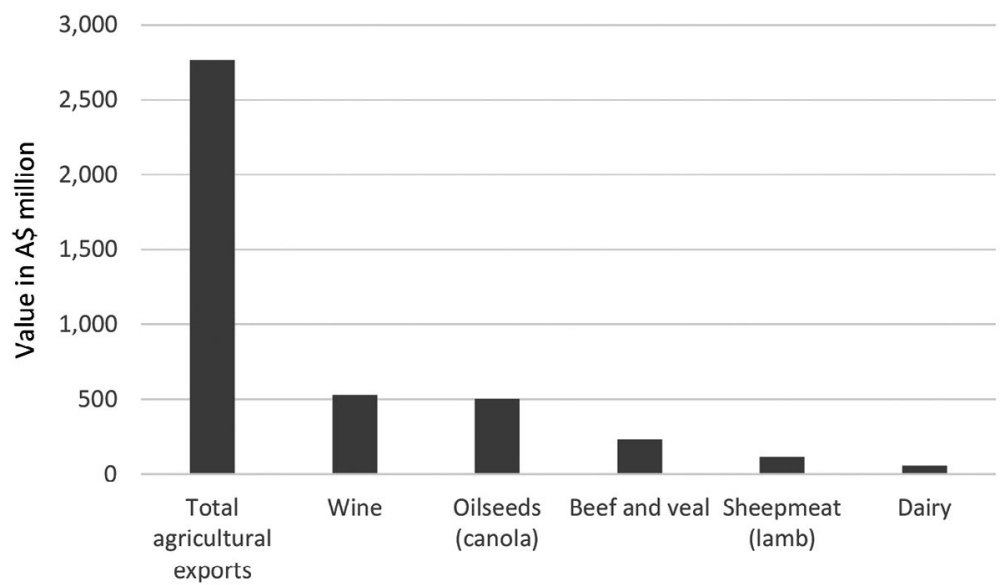

Figure 2. Value in AUD of Australian exports of key agricultural products to the EU in 2013-14

Source: ABARES 2014. 
However, like the USA and Japan, the EU employs strict quotas and high tariffs for a number of agricultural products that act as significant barriers to Australia's exports. Figure 3 compares the extent of tariff measures in both Australia and the EU for key agricultural commodities.

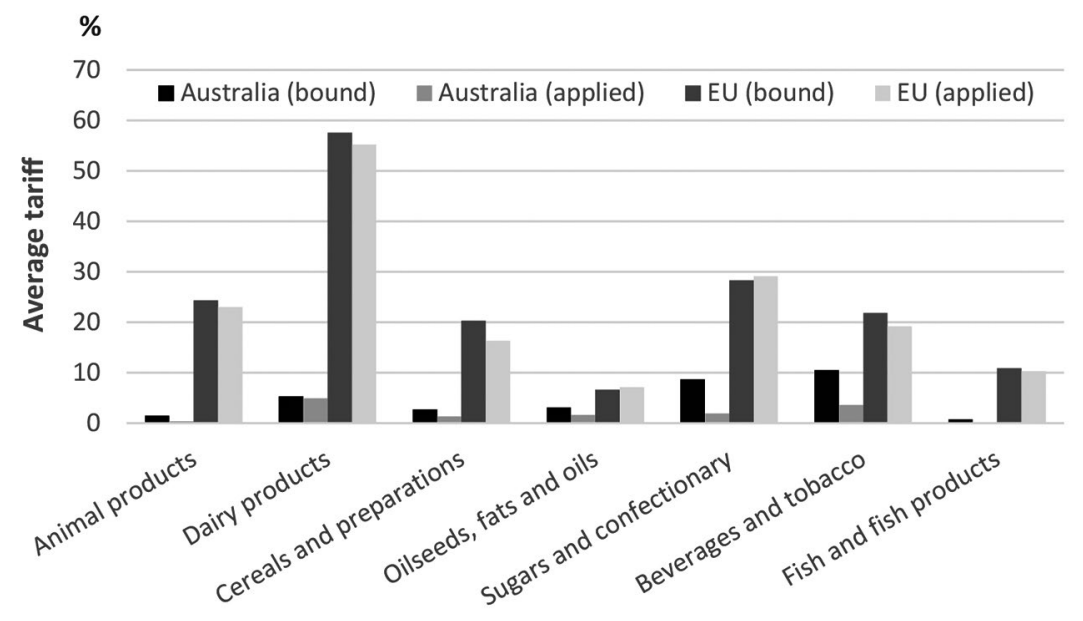

Figure 3. Average bound and applied tariffs for Australia and the EU of selected trade categories

Source: WTO 2014

As well as tariffs and quotas, the EU continues to subsidise its agricultural sector in a complicated system of payments, governed by the CAP. Since 1986-88, the EU has worked to reduce its level of agricultural support, which now sits at 19 per cent as measured by the percentage producer support estimate (PSE), ${ }^{2}$ declining from a rate of 39 per cent-the Organisation for Economic Co-operation and Development (OECD) average sits at 18 per cent (OECD 2014). Though the EU's level of support to farmers is declining, that support remains high when compared with Australia's rate of PSE of just 2 per cent (Table 1). The EU's above average support highlights that even beyond the considerable reforms of the CAP, support to European farmers continues to be a trade barrier. Conversely, Australia places no tariffs on fresh or unprocessed products. There is, however, a flat rate of 5 per cent on almost all processed agricultural products (PAPs) of which the EU is a large exporter.

2 The percentage producer support estimate (PSE) represents policy transfers to agricultural producers, measured at the farm gate and expressed as a share of gross farm receipts. 
Table 1. Level of agricultural support in Australia and the EU

\begin{tabular}{|l|r|r|r|r|r|r|}
\hline $\begin{array}{l}\text { Country/ } \\
\text { Customs } \\
\text { area }\end{array}$ & $\begin{array}{c}\text { Product } \\
\text { support } \\
\text { estimate } \\
\text { (\%) }\end{array}$ & $\begin{array}{c}\text { Highly } \\
\text { trade } \\
\text { distorting } \\
\text { (\%) }\end{array}$ & $\begin{array}{c}\text { Price } \\
\text { differential } \\
\text { - country } \\
\text { to border }\end{array}$ & $\begin{array}{r}\text { TSE }^{\star} \text { as } \\
\text { per cent } \\
\text { of GDP }\end{array}$ & $\begin{array}{c}\text { Single } \\
\text { commodity } \\
\text { transfer (\%) }\end{array}$ & $\begin{array}{c}\text { Key } \\
\text { commodities } \\
\text { subsidised } \\
(\%)\end{array}$ \\
\hline Australia & 2 & 11 & 1 & 0.1 & None & None \\
\hline EU & 19 & 27 & 1.05 & 0.8 & 26 & $\begin{array}{l}\text { Sugar (13), } \\
\text { beef and veal } \\
\text { (24), poultry } \\
(12)\end{array}$ \\
\hline
\end{tabular}

* TSE = total support estimate

Source: OECD 2014.

Much of the consternation surrounding the CAP also relates to the EU's use of export subsidies, even though these have also been significantly reduced in recent years. In 2014, export subsidies were $€ 12$ million, compared with $€ 67$ million in 2013, and $€ 3.7$ billion in 2004 (OECD 2014). The EU continues to use trade-distorting subsidies, with average prices received by EU farm producers remaining 5 per cent above world prices, compared to Australia where farmers receive average prices that are at par with world prices (OECD 2014). Overall, while the EU market has declined in importance for Australian agricultural producers, there is still an opportunity and appetite to negotiate reforms to the tariff and quota arrangements of the EU in some key markets: oilseeds, beef and veal, lamb and mutton, dairy and wheat—each explored in turn now.

The EU is a very significant market for Australian oilseeds, with canola alone making up 18 per cent of all agricultural exports to the EU. Demand for that product has skyrocketed since 2006-07. The EU Renewable Energy Directive (2009) further intensified demand, with canola being used in the production of biodiesel. The market is not subject to tariffs or quotas, but reflecting the product's use in biodiesel, there are two significant European certification schemes for sustainable production that Australian exporters are required to adhere to. In essence, those schemes enforce sustainability standards in the production of canola along the whole supply chain-'from the paddock to the Peugeot' - with current requirements demanding a 35 per cent reduction in greenhouse gas 
emissions in comparison to fossil fuels ${ }^{3}$ (EC 2015). Those standards will increase to a minimum 50 per cent reduction in 2017 and 60 per cent reduction in 2018. However, based on current scientific evidence, Australian producers are likely to meet those thresholds. Somewhat ironically, it is unclear whether European oilseed producers will be able to do the same. While the EU market pays a premium price for Australian canola, almost two-thirds of the certification schemes' criteria are irrelevant for the Australian environment so there are significant opportunities for negotiators in this sector.

Beef and veal exports have also enjoyed strong recent growth between 2007-08 and 2013-14, with exports to the EU more than tripling from 7.3 thousand tonnes to 22.8 thousand tonnes, including an extraordinary 33 per cent increase from 2013 to 2014 . The continued growth in grain-fed beef shipments has allowed Australia to diversify its markets in the EU, with further growth in exports to Italy (up 9 per cent), the Netherlands (up 29 per cent) and Denmark (up 12 per cent) (MLA 2015). Australian beef and veal, though they face no in-quota tariff, are restricted by two major quotas, the high-quality beef(HQB) Hilton quota (Australia's share of this quota is 7,150 tonnes swt/year) that has a utilisation average from 90 per cent to 100 per cent, and the HQB grain-fed quota $(48,200$ tonnes swt/year—on a 'first come first served' import allocation).

To put this in perspective, Australia exported over one million tonnes of beef and veal globally in 2013-14 (ABARES 2014), so the EU quotas are hugely restrictive. Nevertheless, the EU remains the highest value market for Australian beef on a per tonne basis, averaging $A \$ 10,550 /$ metric tonne in 2014 (MLA 2015). Australia's access to the HQB Hilton quota and grain-fed $\mathrm{HQB}$ quota means that the majority of cuts exported to the EU are high quality and subsequently of high value (MLA 2015), and the fact that the quota is almost always filled suggests there would be significant gains for Australian exporters if that quota could be increased. In contrast to US and Canadian beef, Australian beef does not contain hormones and is therefore not subject to the EU's ban on hormone-treated beef.

3 To be considered sustainable, biofuels must achieve greenhouse gas savings of at least 35 per cent in 2015 in comparison to fossil fuels, 50 per cent in 2017, and 60 per cent in 2018, but only for new production plants; cannot be grown in areas converted from land with previously high carbon stock such as wetlands or forests; and cannot be produced from raw materials obtained from land with high biodiversity such as primary forests or highly biodiverse grasslands. 
The Australia-EU relationship in the dairy sector has been strained for the better part of four decades. In contrast to Australia, New Zealand dairy producers have enjoyed privileged access to the EU for New Zealand butter and cheese dating back to the United Kingdom's (UK) accession to the EU in 1973. At that time, New Zealand's access to the UK market was safeguarded on the grounds that New Zealand's economy was so utterly dependent on it. For similar reasons those privileges were subsequently extended to an EU-wide bound commitment in the Uruguay Round negotiations (Kenyon \& Lee 2006). No such privileges were afforded to Australian producers - then or since-with the result that dairy exports to the EU have been limited.

The Australian dairy industry faces perhaps the most restrictive barriers with quotas and in-quota tariffs existing for most products: butter is limited to 10,000 tonnes from all third parties and an in-quota tariff of $€ 950$ per tonne; cheddar, of which Australia is a large exporter, is limited to 15,000 tonnes from all third parties and an in-quota tariff of $€ 210$ per tonne; all other cheeses are limited to 19,500 tonnes from all third parties with in-quota tariffs ranging from $€ 690$ to $€ 1,060$ per tonne, depending on the variety of cheese. Not surprisingly then, dairy exports from Australia have declined in all categories since 2007-08 and the main market for Australian exports - the sale of cheese to the UK-has also declined over recent years. ${ }^{4}$ The EU accounts for just 2 per cent of Australia's exports, and in-quota tariffs are partly to blame. However, of all the agricultural commodities exported to the EU, the dairy industry is arguably most affected by NTBs, especially in the areas of environmental standards and geographic indicators. On the latter there is little prospect that the EU will soften its stance in the foreseeable future (see below).

Interestingly, as with dairy products, NZ exports of lamb were similarly privileged after the UK's accession to the EU and again Australian producers enjoyed no such access. Today, lamb and mutton exports to the EU are limited by a 19,186 tonne carcass weight equivalent tariff rate quota (TRQ) — a quota that is almost always filled. When compared with New Zealand's quota (just over 228,000 tonnes), it is clear just how significant New Zealand's privileged market access is. Indeed, the volume of lamb exports to the EU has increased slightly since 2006-07, with the main market being the UK. Importantly, the value of lamb exports

4 This correlates with a reduction in production of dairy product in Australia between 2007-08 and 2013-14, though average export unit values have continued to increase over time. 
has almost doubled in the last five years, with the UK and EU attracting high-end, high-value lamb exports from Australia. At the other end of the value spectrum, mutton exports to the EU have also increased but neither the volume nor the value is very significant. Nevertheless, as is the case with beef exports, any leeway made in relation to lamb quotas would see considerable benefits accrued to Australian exporters, although New Zealand exporters might be less than enthusiastic about such an outcome.

Like lamb and dairy exports, Australian sugar exports to the UK had a similar (but sadder) history with the demise of the Commonwealth Sugar Agreement in 1973 when the UK joined the EU. Again, the Uruguay Round failed to deliver similar market access arrangements for Australian sugar, and that sector has been exposed to significant tariffs and quotas in almost all major foreign markets as a consequence of the EU and USA in particular being major sugar producers themselves. Australian exports face a quota of just below 10,000 tonnes and an in-quota tariff of $€ 98$ per tonne; the quotas of Brazil (334,000 tonnes) and Cuba (69,000 tonnes) as well as all other third parties (254,000 tonnes) dwarf the Australian figure. In recent years, sugar exports decreased between 2006-07 and 2011-12, though they have rebounded since. Exports to the EU are statistically insignificant, but for reasons mentioned above they will likely prove to be a sticking point in trade negotiations not least owing to the controversies of the Australia-United States Free Trade Agreement (AUSFTA) negotiations. In that case, the sugar industry was assured of positive outcomes but in reality was completely removed from the agreement.

Australian wine exports to the EU have decreased significantly with the volume of imports into the major markets-Germany, Ireland, the Netherlands, and the UK-more than halved since 2006-07. However, the value of these exports remains very high. Tariffs on Australian wine are at 3 per cent-described by one interviewee as 'a nuisance more than anything else' - and the treaty-level Australia-EU wine agreement has established an effective forum in which to resolve emerging issues. Indeed, while the EU's regulations relating to geographic indicators and environmental sustainability (and associated labelling) are still problematic for Australian wine producers, both bilateral and multilateral dialogues are effective in addressing them, thus limiting the value of including wine in negotiations for an EU-Australia FTA. 
Less significant markets for Australian agricultural products include fish and seafood exports and wheat. However, the EU is a net exporter of both commodities, so the potential to increase market share in those products is limited, with two exceptions. The first is the opportunity to expand exports of specialised grains, building on Australiass reputation for producing high-quality durum wheat for use in pasta production. The second opportunity lies in the area of plant energy systems. However, in both cases the EU's standards in relation to environmental sustainability and genetic modification could prove to be prohibitive to trade.

\section{Expectations from an Australia-EU FTA}

As the previous section indicated, despite the gains made from the Uruguay Round of General Agreement on Tariffs and Trade (GATT) and reforms to the EU's CAP, significant trade barriers continue to impede trade in agricultural products between the EU and Australia. Certainly, the existence of highly restrictive tariffs and quotas in the EU suggests that trade negotiators could reasonably be expected to begin negotiations there. But the experience of other FTAs is sobering. In the lead-up to the AUSFTA, for example, it was predicted that there would be significant gains for the Australian agricultural industry as the USA maintained some of its highest trade barriers for agricultural goods (Krever 2006). The outcomes were far from ideal. Though there were seemingly positive changes made with respect to in-quota tariff removals in beef and dairy, safeguards were included by the USA ensuring that tariffs would remain in place in case of declines in the domestic value of those commodities (Clarke \& Gao 2007; Krever 2006). Sugar was excluded from the agreement altogether. In Australia’s FTA with Japan, most Australian tariff lines will be reduced to zero. However, for cheese, various vegetables and a number of fresh and dried fruits, tariffs remain and they are not trivial. With respect to NTBs, in the Australia-Japan FTA little progress was made, with the text simply stating that each party shall not implement a measure unless it is allowable under the WTO and that such measures need to remain transparent.

In contrast, CETA did deliver significant tariff reductions on agricultural products, with almost all tariff eliminations to be undertaken immediately. However, a key difference with the case of Australia mutes one's optimism: the EU has been a significant net agricultural exporter to Canada for a number of years (Viju \& Kerr 2011), which is a fundamentally different 
relationship to that enjoyed by Australia and the EU. Success in agriculture in an Australia-EU FTA will almost certainly rely on Australia's willingness to offer concessions in other sectors.

In reality, the major opportunities for trade liberalisation in agricultural trade between Australia and the EU lie in the area of NTBs. These can be divided into technical and nontechnical measures and they are regulatory in nature (WTO 2013: 25).

Technical measures include SPS standards (covered by the SPS agreement); rules for product weight, size or packaging; ingredient or identity standards; mandatory labelling; shelf-life restrictions; and import testing and certification procedures. Nontechnical measures include bureaucratic restrictions, subsidies or other legal measures that hinder trade, such as failure to provide adequate and effective intellectual property protection (Nathan Associates 2013: 2).

Both types may have legitimate purposes, especially in the eyes of enforcers, but both can also be misused to covertly impede trade. They may be designed to limit trade or they may have that effect because of the way they are implemented, either with a lack of transparency, inefficiency or corruption.

Estimating the costs of NTBs is therefore understandably complex (Boza 2013), but estimates run into the millions per annum. Beghin and Melatos (2012) examined the impact of Australia's quarantine regime on pig meat imports. They concluded that the effects on welfare and trade of the Australian quarantine regime were very significant and estimated that the withdrawal of the regime resulted in a staggering welfare gain to consumers of $\mathrm{A} \$ 409$ million and the expansion of revenue to three exporting nations of $\mathrm{A} \$ 479$ million.

The WTO's Sanitary and Phytosanitary and Technical Barriers to Trade agreements do allow countries to adopt appropriate measures to protect human, plant and animal health, but to reduce compliance costs and minimise disputes, countries are encouraged to base their domestic technical regulations or standards on those developed by international organisations, including the Joint FAO/WHO Codex Alimentarius Commission (Codex) for food safety; the Office International des Epizooties (OIE) for animal health; and the International Plant Protection Convention (IPPC) for plant health (WTO 2010). However, member 
states are allowed to impose more stringent guidelines under the GATT if a risk assessment—supported by sufficient scientific evidence-deems such an approach to be justified.

When third countries question those more stringent guidelines, they raise a specific trade concern (STC) with the appropriate committee. If the number of bilateral STCs raised in the WTO is any indication of the level of NTBs used by countries, then the EU and Australia have much to gain by exploring opportunities for regulatory cooperation. Figures from Horn et al. (2013: 737) (Figure 4) illustrate that the EU and Australia received the greatest number of STC notifications in relation to SPS issues, while Figure 5 illustrates the same statistics for STCs relating to TBTs. Clearly, both jurisdictions have imposed barriers to trade that third countries find worrisome. Somewhat ironically, the fact that both the EU and Australia impose comparatively stringent regulations on imports suggests that they may have more in common than either side cares to admit.

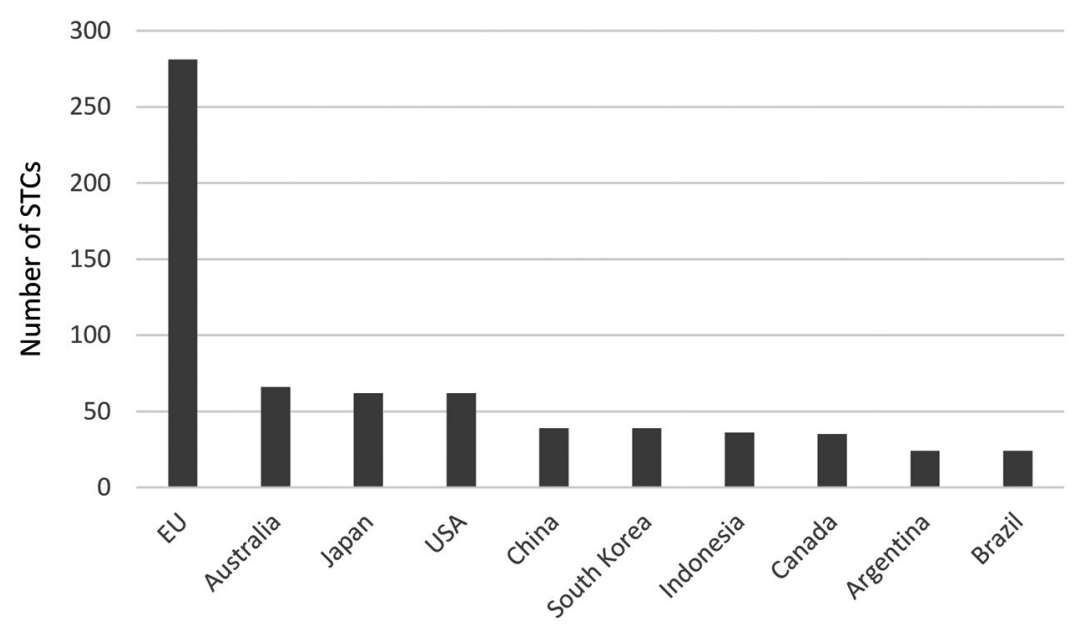

Figure 4. Members that most frequently face SPS 'Bilateral' STCs Source: After Horn, Mavroidis \& Wijkstrom 2013: 737. 


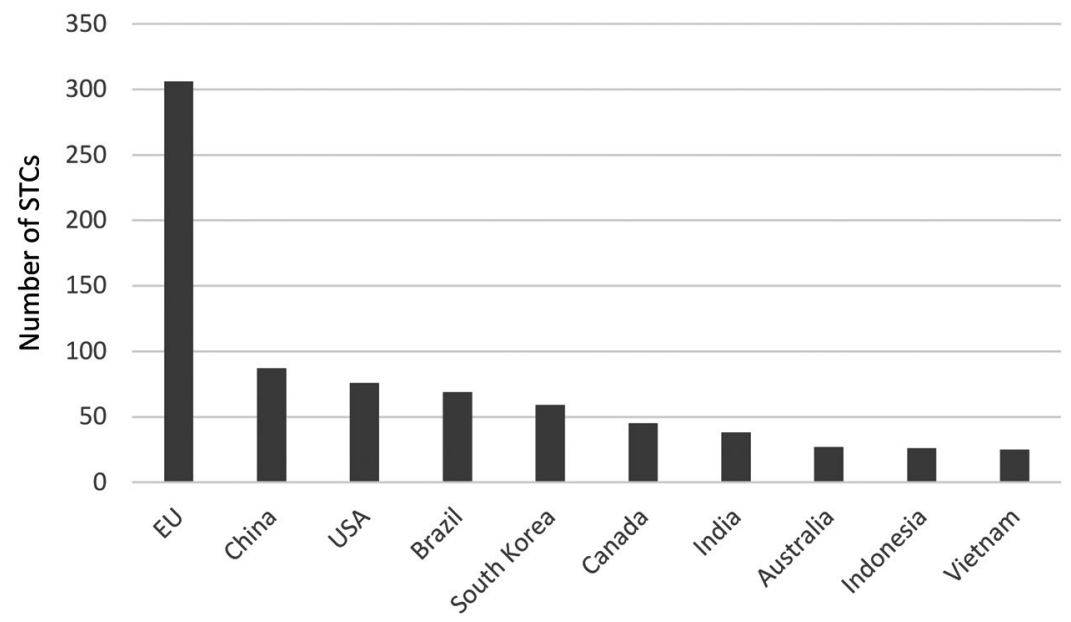

Figure 5. Members that most frequently face TBT 'Bilateral' STCs Source: After Horn, Mavroidis \& Wijkstrom 2013: 737.

Increasingly, NTBs reflect with public policy objectives and consumer preferences and they therefore raise issues of far greater complexity than tariffs. As Philip Stephens of the Financial Times put it:

The nature of free trade deals has changed. They used to be about tariffs. Now they focus on regulatory standards and norms, intellectual property rights, data privacy and investment protection. These are issues that cut deep across national political and cultural preferences. Lowering import duties is one thing; persuading voters to relax the rules on data protection or accept new rules on food safely is another (Stephens 2016).

Furthermore, while the purpose of some NTBs is very specifically to restrict trade-for example in the prohibition of harmful productsoften that restriction is an unintended, perverse consequence of pursuing a given public policy objective. As the WTO phrased it:

[d]ivergence can occur for different reasons. It may be a reflection of different social preferences and values. In this case, the notion of 'levelling the playing field' in trade relations takes on an additional layer of complexity - the search cannot be for uniformity in cases where an attempt to homogenize societal preferences would be an intrusive step too far. Cooperation in this case can only be about avoiding unnecessary friction or unwarranted discrimination (WTO 2013: 25). 
Where do NTBs exist in the Australia-EU agri-trade relationship? The following issues all impede trade to varying degrees on either side of the relationship:

- custom surcharges

- high level of food and safety standards resulting in high SPS measures that are more stringent than international standards or that are not relevant to the exporting environmental conditions

- long and difficult authorisation procedures

- labelling requirement laws

- direct and indirect government support through tax relief and concessions or protective legislation to EU farmers

- traceability and labelling of biotechnology foods

- maximum limits on mycotoxins for a variety of foodstuffs (including cereals, fruit and nuts)

- product process, production or labelling requirements relating to the classification of 'organic' foods.

Following Berden et al. (2009), NTBs and regulatory divergence can have two main effects:

a. Those NTBs that increase the cost of doing business for firms result in increased commodity prices for end users, because firms increase prices to cover the higher cost of doing business, which constitutes a welfare loss to society.

b. Those NTBs that restrict market access for firms increase the market concentration and economic power (and thus revenue profits) of companies in the importing country, with the result that commodity prices may increase anyway_-reducing welfare gains overall—and welfare is redistributed away from consumers towards domestic producers (i.e. protecting them, not consumers).

NTBs can be especially cumbersome for small and medium-sized enterprises in exporting countries, which lack the resources to deal with multiple regulatory regimes in multiple markets (noting that when dealing with the EU, sometimes there are multiple regimes at the level of member states). 
An oft-suggested method of overcoming these barriers is mutual recognition of regulations in exporting and importing countries (see, for example, Nicolaidis \& Shaffer 2005; Trachtman 2007; and Kerber $\&$ van den Bergh 2008). Mutual recognition across different regulatory jurisdictions assumes an equivalence of regulatory and public policy goals across jurisdictions but accepts that there are differences in regulatory approach or detail in how those goals are met; in this way, it is possible to 'mutually recognise' (usually with exceptions) each other's regulation so as to facilitate trade. Kerber and Van den Bergh (2008: 447) suggest 'mutual recognition is often recommended as a nearly ideal solution for removing obstacles to free trade without embarking on a pathway to harmonisation'.

Mutual recognition has been a part of trade negotiations and bilateral agreements for some time; however, this has generally been limited to conformity assessment procedures and, more often than not, specifically excludes SPS measures (see, for example, the multiple MRAs of the $\mathrm{EU}$, the Australia-Singapore MRA, CETA and the China-Australia FTA). Conformity assessment measures in these agreements have always related to technical products or medicines (e.g. telecommunications and electronics) whereby a consumer may be at risk or a product may simply not work when imported. However, there is precedent for mutual recognition to spread beyond simply technical measures to those measures affecting agricultural products (see, for example, the TransTasman Mutual Recognition Arrangement (TTMRA) between Australia and New Zealand).

The arguments against using mutual recognition centre on fears that regulatory competition can undermine public interest concerns such as health and safety standards and environmental goals, and lead to lowestcommon-denominator outcomes or a 'race to the bottom'. It follows, therefore, that the acceptance of 'equivalence' in regulation between jurisdictions demands a high degree of trust between trading partners. Arguably, this was particularly problematic in the context of the WTO's multilateral trade negotiations, but there is some justification for suggesting that it is less of a problem when states negotiate bilateral or plurilateral trade agreements. In the case of an FTA between Australia and the EU, the potential to embark on significant arrangements to mutually recognise each other's regulatory frameworks is, arguably, very large, for three reasons. 
First, the underlying intent of many of the NTBs in the agricultural sector in both jurisdictions is the same. Australia and the EU have similar, very stringent, robust regulatory frameworks governing the agricultural sector. Whether in the area of waste management, water and air pollution control, management of non-point source pollution, tracing systems, or even occupational health and safety requirements, the objectives of the respective frameworks are very similar. Moreover, the high level of institutional capacity in both markets ensures that the regulatory regimes are upheld, thus providing the necessary trust for a form of mutual recognition. Nevertheless, there have been some major disagreements between Australia and the EU regarding the use of sanitary measures since the WTO SPS agreement came into force.

As has been the case in disputes between the EU and Canada, these disagreements relate to both the science itself and whether or not science should be the sole, or a contributing, factor in the establishment of sanitary import regulation (Viju \& Kerr 2011). For example, Woolcock (2007: 6) suggests:

[owing to] shifts in European consumer preferences in favour of higher food safety and environmental standards, the EU has sought to use the precautionary principle in the regulation of risk which implies an approach that views science-based risk assessment as an important but not the only criterion.

Another source of tension is the 'blanket' approach of some of the EU's import requirements aimed at sustainability objectives. In many cases, those requirements are irrelevant to the Australian landscape. Australia could, for example, seek agreement from the EU that a thorough review of EU schemes for Australia be undertaken, so that at the very least those conditions that do not affect Australia could be excluded.

Second, the gains from cooperating on regulatory divergence accrue to both sides of the trade, particularly for NTBs in the agricultural sector. As Figure 4 demonstrated, the EU and Australia are both onerous in their regulatory regimes in the eyes of rest of the world. Thus, there is much to be gained from exploring opportunities to cooperate. In contrast to the situation with tariffs and quotas, regulatory cooperation on NTBs would deliver welfare gains to all. 
The third reason relates to the increased influence the EU and Australia would be able to exert in non-trade forums if they could cooperate more on NTBs, especially in emerging issues. There is no point in pursuing public policy objectives in one forum, if they are going to be undermined by WTO trade rules; this is particularly the case in the 'trade environment' domain:

Convergence between trade and public policy NTBs requires greater coherence between trade rules and policies, norms and standards in other areas of international cooperation (WTO 2013: 7).

If the EU and Australia-two jurisdictions with very high levels of SPS protection-were to establish common ground at an early stage in the trade of new products, they could possibly prevent NTBs from setting in.

For example, momentum is building internationally to address climate change, and domestic regulation to mitigate greenhouse gas emissions has already been brought in front of the WTO dispute settlement panel. Four WTO disputes have been filed since 2010 that challenge government programs supporting renewable energy, and a number of related disputes have yet to reach the WTO (Meyer 2013). Other emerging areas relate to environmental tariffs at the border, particularly in the area of border carbon adjustments to 'level the playing field' between those countries or regions that have a robust climate mitigation policy, vis-à-vis those without one. What is almost certain is that the conflation of environmental concerns with international trade is likely to increase in the coming years, but the WTO Committee on Trade and Environment is unlikely to find meaningful solutions in the foreseeable future.

Another potential future NTB to trade and investment is 'nanotechnology'. Berden et al. (2009: 85) suggest that 'while the technique itself is not being challenged, the regulatory, trade and investment consequences of introducing nanotechnology can potentially lead to high NTBs, especially in the food-producing and processing sectors'. Further advancements in the area of genomics, as well as increasing pressure from consumers and/ or companies in relation to the traceability of agricultural products, are other areas of potential future tension. To the extent that bilateral and plurilateral FTAs can be used to mitigate such disputes, they should be. 


\section{Conclusion}

Given the failure of the Doha Development Agenda to secure the further reduction of tariffs in the agricultural sector, or to overcome some of the complex extant issues in the SPS and TBT agreements, it is hardly surprising that OECD countries quickly found an alternative mechanism through which to pursue trade liberalisation. The fact that so many bilateral and regional FTAs have been concluded in recent years is testament to the fact that the gains must surely outweigh the significant transaction costs that so many simultaneous negotiations incur. Indeed, the capacity for these agreements to tackle the 'new trade agenda' issues that this volume examines - the expansion of services trade, the rise of TBTs and the shifting geopolitical sands in the international system of trade- has no doubt spurred the announcement of the Australia-EU FTA negotiations. However, as our analysis above illustrates, the potential for an Australia-EU FTA to deliver significant market access concessions in agriculture is limited; gains in relation to tariffs and quotas are likely to be sector specific and limited. Nevertheless, there are significant opportunities in the negotiations to overcome many of the NTBs that plague the relationship, in both the SPS and TBT domains.

The reasons lie in the fact that Europe and Australia are more similar than either would care to admit: both have strong regulatory regimes relating to biosafety and environmental sustainability and as a result both enjoy enviable reputations for clean and green agricultural sectors; both have strong institutional arrangements to ensure risk frameworks are enforced; and both would prefer to see a gradual return to the WTO for all-matterstrade. And with the rise of Asia and the Middle East as export markets, politicians and bureaucrats in Brussels and Canberra have been allowed to settle into a comfortable détente, in the knowledge that they now have more in common than ever before. These factors combined mean that a comprehensive and considered review of where regulatory coherence could be achieved in agriculture is both desirable and feasible. As the reforms of Australia's biosafety regime relating to pork demonstrated, the welfare gains that arise from removing TBTs can be enormous.

That said, there have been and remain profound differences in the way the EU and Australia reconcile public policy objectives with trade liberalisation. One area that is likely to prove particularly divisive in the negotiations is that of geographic indicators. Past FTAs have 
indicated that the EU has very little motivation to concede on geographic indicators, but Australian negotiators will need to be careful to ensure that tensions over geographic indicators don't scupper market access gains in other areas from being realised. In short, we are cautiously optimistic.

\section{References}

ABARES (Australian Bureau of Agricultural and Resource Economics and Sciences) (2014), Agricultural Commodity Statistics (ABARES: Canberra).

Beghin, John \& Mark Melatos (2012), 'The trade and welfare impacts of Australian quarantine policies: The case of pigmeat', World Economy, 35(8): 1006-21. doi.org/10.1111/j.1467-9701.2012.01459.x.

Berden, Koen G., Joseph Francois, Martin Thelle, Paul Wymenga \& Saara Tamminen (2009), Non-Tariff Measures in EU-US Trade and Investment-An Economic Analysis (ECORYS Nederland BV: Rotterdam). Available at trade.ec.europa.eu/doclib/docs/2009/ december/tradoc_145613.pdf.

Bonciu, Florin \& Marcel Moldoveanu (2014), 'The proliferation of free trade agreements in the post-Doha Round period: The position of the European Union', Procedia Economics and Finance, 8: 100-105. doi.org/10.1016/S2212-5671(14)00068-9.

Boza Martínez, Sofia (2013), 'Assessing the Impact of Sanitary, Phytosanitary and Technical Requirements on Food and Agricultural Trade: What Does Current Research Tell Us?', SECO / WTI Academic Cooperation Project Working Paper Series, no. 2013/02. Available at dx.doi.org/10.2139/ssrn.2614352.

Clarke, Andrew \& Xiang Gao (2007), 'Bilateral free trade agreements: A comparative analysis of the Australia-United States FTA and the forthcoming Australia-China FTA', UNSW Law Journal 30(3): $842-54$.

Costa, Catherine, Michelle Osborne, Xiao-guang. Zhang, Pierre Boulanger \& Patrick Jomini (2009), Modelling the Effects of the EU Common Agricultural Policy, Staff Working Paper (Productivity Commission: Melbourne). 
DFAT (Department of Foreign Affairs and Trade) (2015), 'AustraliaEuropean Union Free Trade Agreement'. Available at dfat.gov.au/trade/ agreements/aeufta/Pages/aeufta.aspx, last accessed 2 December 2015.

DFAT (2017a), 'EU Economy Factsheet'. Available at dfat.gov.au/geo/ europe/european-union/Pages/european-union.aspx.

DFAT (2017b), Composition of Trade 2014 (DFAT: Canberra).

EC (European Commission) (2015), 'Sustainability Criteria'. Available at ec.europa.eu/energy/node/73, last accessed 7 December 2015.

Horn, Henrik, Petros C. Mavroidis \& Erik N. Wijkstrom (2013), 'In the shadow of the DSU: Addressing specific trade concerns in the WTO SPS and TBT committees', Journal of World Trade 47(4): 729-60.

Hussey, Karen \& Donald Kenyon (2011), 'Regulatory divergences: A barrier to trade and a potential source of trade disputes', Australian Journal of International Affairs 65(4): 381-93. doi.org/10.1080/1035 7718.2011 .586668 .

Irwin, Douglas A. (2015), Free Trade under Fire, 4th edition (Princeton University Press: New Jersey). doi.org/10.1515/9781400866182.

Kenyon, Donald \& John Kunkel (2005), 'Australia and the European Union in the World Trade Organisation: Partners or adversaries?', Australian Journal of International Affairs 59(1): 55-69. doi.org/10.10 80/1035771042000332048.

Kenyon, Don \& David Lee (2006), The Struggle for Trade Liberalisation in Agriculture: Australia and the Cairns Group in the Uruguay Round (Department of Foreign Affairs and Trade: Canberra).

Kerber, Wolfgang \& Roger van den Bergh (2008), 'Mutual recognition revisited: Misunderstandings, inconsistencies, and a suggested reinterpretation', KYKLOS 61(3): 447-65. doi.org/10.1111/j.14676435.2008.00412.x.

Krever, Tor (2006), 'The US-Australia free trade agreement: The interface between partisan politics and national objectives', Australian Journal of Political Science 41(1): 51-69. doi.org/10.1080/ 10361140500507286. 
Meyer, Timothy (2013), 'Energy subsidies and the World Trade Organization', ASIL Insights 17(22). Available at www.asil.org/insights/ volume/17/issue/22/energy-subsidies-and-world-trade-organization.

MLA (Meat and Livestock Australia) (2015), 'Overseas markets Europe and Russia'. Available at www.mla.com.au/Prices-markets/ Overseas-markets/Europe-Russia? \&session-id=af3d341e31b1449cbb 82d2de37174092, last accessed 10 December 2015.

Nathan Associates Inc (2013), 'Nontariff Barriers to Trade: Regional Agricultural Trade Environment (RATE) Summary. USAID Maximizing Agricultural Revenue through Knowledge, Enterprise Development and Trade (MARKET) Project', Submitted to USAID Regional Development Mission for Asia. Available at www.nathaninc. $\mathrm{com} /$ sites/default/files/Nontarriff_barriers.pdf.

Nicolaidis, Kalypso \& Gregory Shaffer (2005), 'Transnational mutual recognition regimes: Governance without global government', Law and Contemporary Problems 68(3/4): 263-317.

OECD (Organisation for Economic Cooperation and Development) (2005), Looking Beyond Tariffs-The Role of Non-Tariff Barriers in World Trade (OECD Publishing: Paris). Available at www.oecd-ilibrary. org/trade/looking-beyond-tariffs_9789264014626-en, last accessed 2 December 2015.

OECD (2014), Agricultural Policy Monitoring and Evaluation 2014: OECD Countries (OECD Publishing: Paris). dx.doi.org/10.1787/ agr_pol-2014-en.

Stephens, Philip (2016), 'US politics is closing the door on free trade', The Financial Times, 8 April. Available at next.ft.com/content/41fd9efafbee-11e5-b3f6-11d5706b613b, last accessed 8 April 2016.

Trachtman, Joel P. (2007), 'Embedding mutual recognition at the WTO', Journal of European Public Policy 14(5): 780-99. doi.org/ 10.1080/13501760701428373.

Viju, Crina \& William A. Kerr (2011), 'Agriculture in the CanadaEU Economic and Trade Agreement', International Journal: Canada's Journal of Global Policy Analysis 66(3): 677-94. doi.org/ 10.1177/002070201106600310. 
Woolcock, Stephen (2007), European Union policy towards Free Trade Agreements, ECIPE Working Paper, no. 03/2007. Available at ecipe.org/publications/european-union-policy-towards-free-tradeagreements/.

WTO (World Trade Organization) (2010), Sanitary and Phytosanitary Measures, The WTO Agreements Series (WTO: Switzerland). Available at www.wto.org/english/res_e/booksp_e/agrmntseries4_sps_e.pdf.

WTO (2013), The Future of Trade: The Challenges of Convergence: Report of the Panel on Defining the Future of Trade (WTO: Geneva). Available at www.wto.org/english/res_e/publications_e/future_of_trade_e.htm.

WTO (2014), 'Tariff Profiles'. Available at stat.wto.org/TariffProfile/ WSDBTariffPFHome.aspx?Language=E, last accessed 13 September 2014. 
This text is taken from Australia, the European Union and the New Trade Agenda, edited by Annmarie Elijah, Don Kenyon, Karen Hussey and Pierre van der Eng, published 2017 by ANU Press, The Australian National University, Canberra, Australia. 